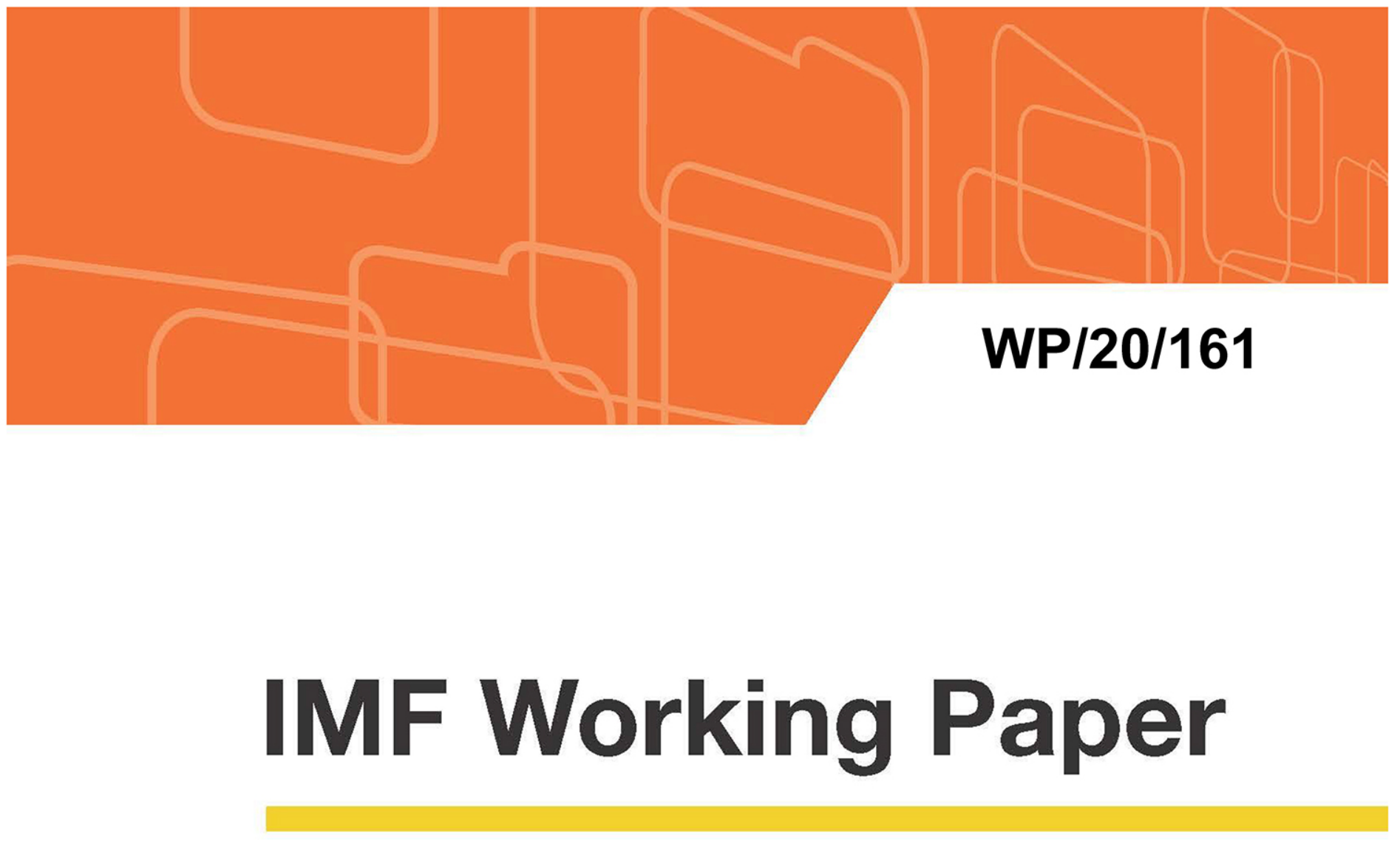

\title{
Financial Intermediation and Technology: What's Old, What's New?
}

by Arnoud Boot, Peter Hoffmann, Luc Laeven, and Lev Ratnovski

IMF Working Papers describe research in progress by the author(s) and are published to elicit comments and to encourage debate. The views expressed in IMF Working Papers are those of the author(s) and do not necessarily represent the views of the IMF, its Executive Boal or IMF management. 


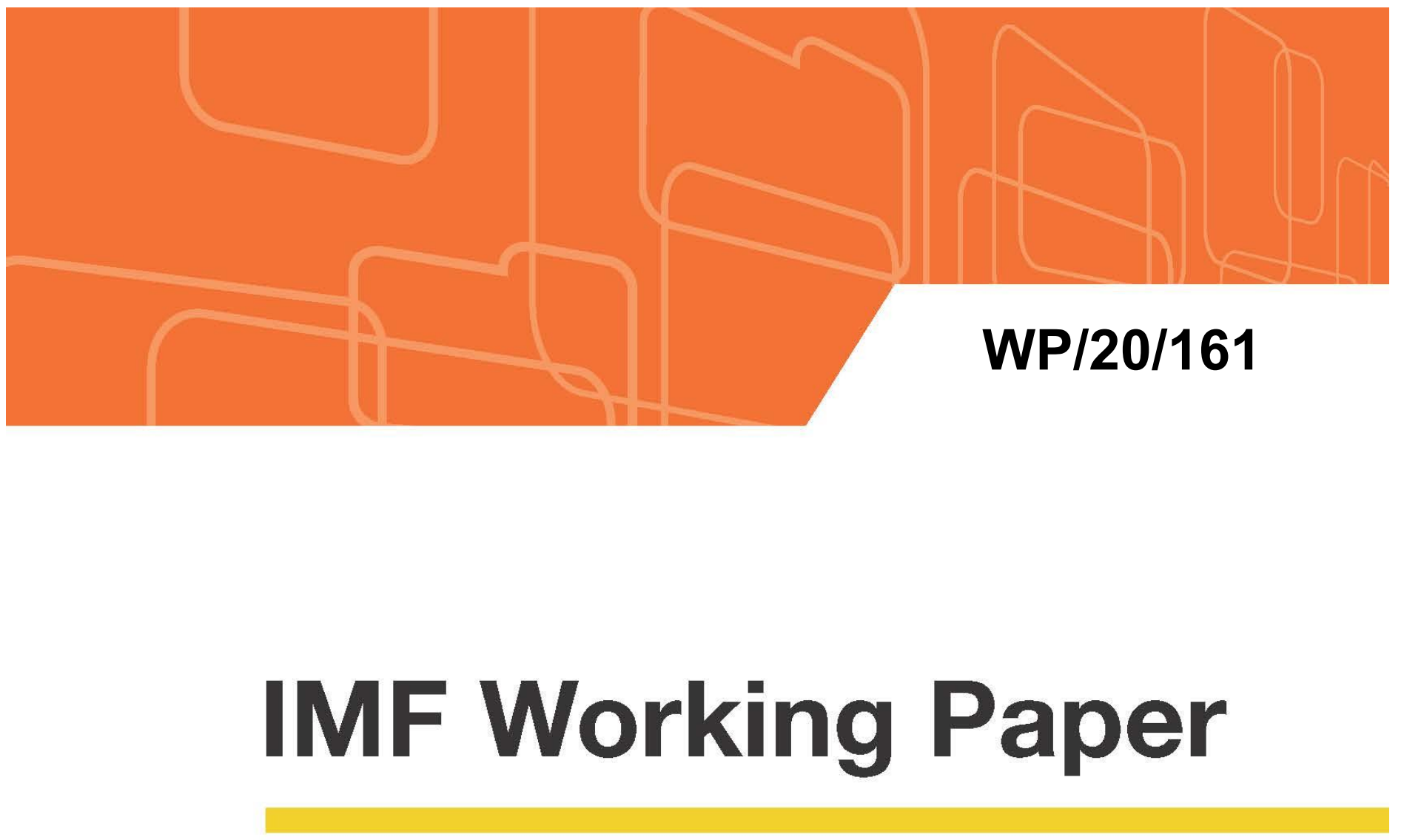

\section{Financial Intermediation and Technology: What's Old, What's New?}

by Arnoud Boot, Peter Hoffmann, Luc Laeven, and Lev Ratnovski

IMF Working Papers describe research in progress by the author(s) and are published to elicit comments and to encourage debate. The views expressed in IMF Working Papers are those of the author(s) and do not necessarily represent the views of the IMF, its Executive Boal or IMF management.

I N T E R N A T I O N A L M O N E T A R Y F U N D 


\title{
IMF Working Paper
}

Research Department

\author{
Financial Intermediation and Technology: What's Old, What's New? \\ Prepared by Arnoud Boot, Peter Hoffmann, Luc Laeven, and Lev Ratnovski ${ }^{1}$ \\ Authorized for distribution by Maria Soledad Martinez Peria
}

August 2020

IMF Working Papers describe research in progress by the author(s) and are published to elicit comments and to encourage debate. The views expressed in IMF Working Papers are those of the author(s) and do not necessarily represent the views of the IMF, its Executive Board, or IMF management.

\begin{abstract}
We study the effects of technological change on financial intermediation, distinguishing between innovations in information (data collection and processing) and communication (relationships and distribution). Both follow historic trends towards an increased use of hard information and less in-person interaction, which are accelerating rapidly. We point to more recent innovations, such as the combination of data abundance and artificial intelligence, and the rise of digital platforms. We argue that in particular the rise of new communication channels can lead to the vertical and horizontal disintegration of the traditional bank business model. Specialized providers of financial services can chip away activities that do not rely on access to balance sheets, while platforms can interject themselves between banks and customers. We discuss limitations to these challenges, and the resulting policy implications.
\end{abstract}

JEL Classification Numbers: G20, G21, E58, O33

Keywords: Financial Intermediation, Financial Innovation, Fintech, Information, Communication.

Authors’ E-Mails: a.w.a.boot@uva.nl; luc.laeven@ecb.int, peter.hoffmann@ecb.int; lratnovski@imf.org

\footnotetext{
${ }^{1}$ Boot is with the University of Amsterdam and CEPR, Hoffmann is with the European Central Bank; Leaven is with the European Central Bank and CEPR; Ratnovski is with the European Central Bank and IMF. The views expressed are those of the authors and do not necessarily reflect those of the European Central Bank or the Eurosystem. We thank Andreas Beyer, Jean-Edouard Colliard, Julia Faltermeier, Florian Heider, Gerard Hertig, Tommaso Mancini-Griffoli, Simone Manganelli, Alberto Martin, Glenn Schepens, Maurit de Vries Robles-Kroon, as well as seminar participants at the ECB and ESCP-Paris for useful comments. Anna Stelzer provided valuable research assistance.
} 


\section{Contents}

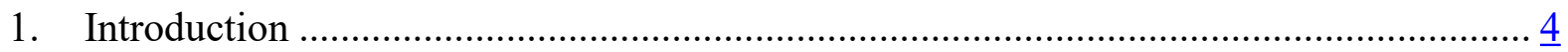

2. Financial intermediation and technological progress ............................................ $\underline{5}$

The role of information and communication in financial intermediation....................... $\underline{5}$

Conceptual framework ........................................................................................ $\underline{6}$

3. Information innovation: Established trends, amplified............................................ $\underline{8}$

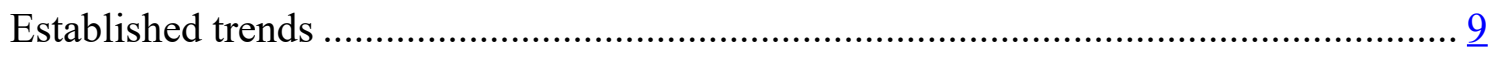

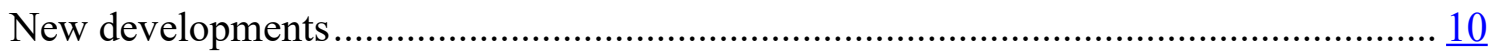

4. Communication innovation: Novel and increasingly pertinent …........................... 12

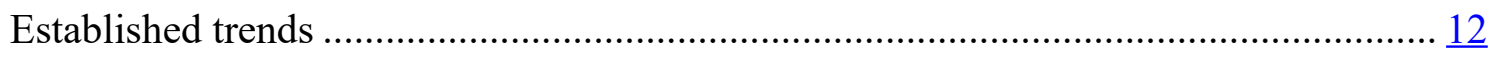

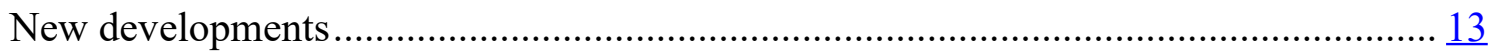

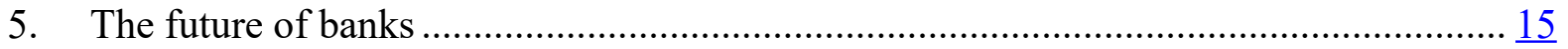

Challenge 1: Horizontal disintegration through specialized competitors ...................... 15

Challenge 2: Re-intermediation through platforms …........................................ 16

Limiting factors and banks' response ............................................................. 18

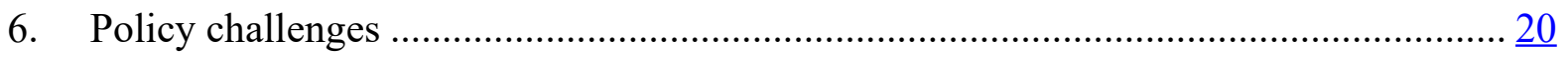

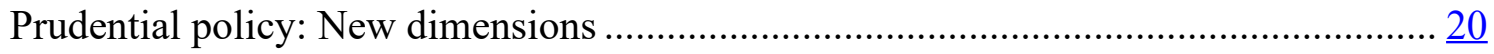

Monetary policy: A new environment ........................................................... 22

Competition policy: Platforms as natural monopolies for communication and data...... 22

Public standards and infrastructures: Focus on data and interconnections ................... 23

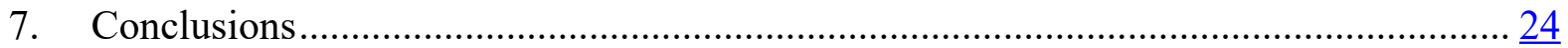




\section{Introduction}

The past decade has presented massive challenges to financial institutions, including the great financial crisis, regulatory reform, low profitability, and deteriorating public trust. Against this background, technological change in the financial industry is accelerating. The ongoing COVID-19 crisis, which has increased demand for digital services, is if anything speeding up this process. Incumbents face disruption from innovative start-ups and large technology firms. This raises a number of important issues. What are the key dimensions of innovation in the provision of financial services? Are they genuinely new developments, or rather the continuation of past trends? Answering these questions is crucial for anticipating future changes in the financial system, gauging their impact on incumbent institutions, and distilling public policy priorities.

In this paper, we develop a simple conceptual framework that distinguishes between two key dimensions of financial innovation, information (data collection and processing) and communication (relationships and distribution) ${ }^{2}$. We argue that both are key ingredients in the financial intermediation process, and allow banks to exert market power through informational and spatial capture. Both are affected by technological change. We identify the proliferation of hard information and the shift away from in-person interactions as longstanding developments. The existing literature offers useful insights that remain valid in an environment where those forces are accelerating.

We contrast the continuation of past trends with more novel developments, such as the rise of machine learning and artificial intelligence enabled by an abundance of (non-financial) data, and the dominance of digital platforms and smartphones. We argue that technological progress may lead to the vertical and horizontal disintegration of the traditional bank business model. Novel communication channels enable specialized providers to side-step banks' distribution networks and offer financial services that do not require access to a balance sheet, for example in the areas of payments and wealth management. Moreover, digital platforms can interject themselves between banks and their customers, introducing another layer of intermediation that captures most rents. In the extreme, this would relegate banks to upstream providers of maturity transformation services.

We also discuss limitations to the entry of specialized financial service providers and digital platforms. Standalone providers of specialized services are constrained by their narrow business models and the fact that they rarely possess a deep balance sheet. While large digital platforms have deep pockets, their reach in the provision of financial services is constrained

\footnotetext{
${ }^{2}$ As will become apparent, communication permits overcoming search and "transportation" frictions.
} 
by their focus on serving retail consumers. This may change, however, due to the rise of cloud computing, which may enable large technology firms to create B2B ecosystems that include large corporate customers. This will likely give technology firms information and communication advantages for the provision of financial services to these clients as well. Banks can attempt to stave off the competitive pressures from platforms and specialized entrants by investing in the digitalization of own business processes. However, besides being costly, such transformation is often impeded by entrenched organizational cultures, reputational risks, and regulatory factors.

Our paper contributes to the literature on technological disruption in finance. Claessens at al. (2018) document the rise of Fintech lending across countries, while Thakor (2019) compares credit provision by banks and non-banks. The overview of Vives (2019) highlights the competitive challenge from large technology firms and its impact on business strategies, whereas Petralia et al. (2019) and Stulz (2019) discuss the impact of Fintech and Bigtech on banking. Compared to this literature, our analysis focuses on articulating the key dimensions of financial innovation - information and communication - and on distinguishing preexisting trends from genuinely new developments in each of these two dimensions. This helps us clarify the economic forces at play, and refine the resulting policy implications.

The remainder of the paper proceeds as follows. Section 2 introduces our analytical framework and briefly discusses the roles of information and communication for financial services provision. Sections 3 and 4 discuss the effects of innovation in each of these fields, respectively, distinguishing between the continuation of past trends and genuinely new developments. Section 5 highlights the horizontal and vertical disintegration of the integrated bank business model as a major threat posed by recent innovation. We discuss the resulting policy implications in Section 6, followed by the conclusion.

\section{Financial intermediation and technological progress}

In this section, we develop a simple conceptual framework to guide our analysis. We argue that information and communication lie at the heart of financial intermediation, and are deeply affected by technology.

\section{The role of information and communication in financial intermediation}

The function of the financial system is to transform savings into investment, which helps to ensure an efficient allocation of resources in the economy. Financial intermediaries focus on overcoming information (moral hazard and adverse selection) and communication ("matchmaking”) frictions that can prevent the efficient allocation of resources. 
To resolve informational frictions, financial intermediaries screen and monitor risky investments on behalf of the savers who lack own capacity to do so (Diamond, 1984). Banks commit to exerting effort by using their financial capital, or "skin in the game" (Hölmstrom and Tirole, 1997). Other financial intermediaries, such as ratings agencies, use their reputation to achieve similar commitment (Boot et al., 1993). Securities underwriters use both reputational and financial exposure to assure customers of the quality of their due diligence. Also, financial intermediaries tend to engage in repeated interactions with their customers. This facilitates the collection, processing, and re-use of customer information (Boot, 2000), and increases the efficiency of monitoring (Lopez-Espinoza et al., 2017).

To resolve communication frictions, financial intermediaries invest in the creation and maintenance of customer relationships and product distribution channels. Banks have historically leveraged upon their branch networks to act as the customers" "first point of contact" for financial services. Other financial intermediaries such as brokers and exchanges specialize in communication to facilitate match-making among interested parties. The role of communication in financial intermediation has received less attention in the literature historically. In this paper we argue that the role of communication in determining the industry structure of the financial sector has been growing, and may now eclipse that of information.

Superior information and communication enable financial intermediaries to exert market power. Private information generates informational capture as outside competitors face adverse selection (Rajan, 1992). Similarly, search, switching, and transportation costs lead to communication-related "spatial" capture, which allows banks to price discriminate among customers (Degryse and Ongena, 2005; Agarwal and Hauswald, 2010; Armstrong and Vickers, 2019), cross-sell additional financial services (Puri and Rocholl, 2008), and enjoy cheap and stable deposit funding (Drechsler et al., 2018).

Since information and communication frictions act as barriers to entry, they make financial services provision less contestable. At the same time, they permit financial intermediaries to generate charter value, which makes them more stable and forward-looking. This, in turn, can benefit customers. For example, banks tend to cushion credit terms for their long-term customers during downturns (Petersen and Rajan, 1995; Bolton et al., 2018).

\section{Conceptual framework}

Innovation in information and communication has been accelerating over the past decades, driven by growing computing power and the proliferation of the internet. While the underlying technological progress is affecting virtually all sectors of the economy, the effects on financial intermediation are particularly profound. This is illustrated by Figure 1. The left 
Panel is based on the European Working Conditions Survey, and shows that Financial Intermediation (blue line) dwarfs all other industries (range indicated by shaded area) in the use of personal computers. In 2015, $89 \%$ of all employees in financial intermediation made heavy use of personal computers in the EU-15 countries. The right panel shows that the increase of automation has led to a steady decline in the number of employees in financial intermediation. Between 1997 and 2018, the number of bank employees declined from 7,300 to 5,500 per million inhabitants in the EU-15, corresponding to a decline of roughly half a million jobs.

Figure 1. Computer use and employment in financial intermediation.
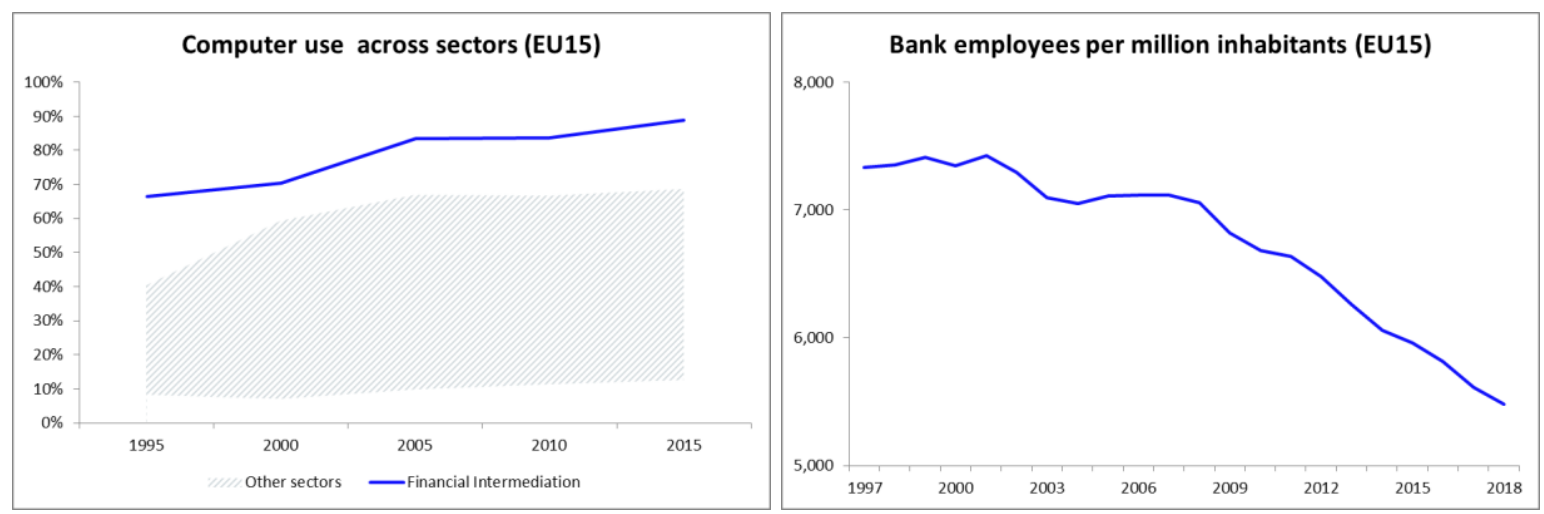

Note. The left Panel shows the shareof employees that report using computer at work, acrross NACE-1 sectors. The blue line shows the share for Financial Intermediation, while the shaded grey area indicates the range for other sectors. Source: European Working Conditions Survey. The right Panel shows the number of bank employees per million inhabitants. Source: ECB Statistical Data Warehouse. All data cover EU15 countries

The financial industry has experienced many waves of technological innovation. Advances on the information side led to the rise of passive investing in the 1980 s and to the credit scoring and securitization revolution in the 1990s. Similarly, innovations in communication included ATMs in the 1970s; telephone banking in the 1980s; attempted entry into banking by supermarket giants Walmart and Tesco in UK in the 1990s; and the increased use of online banking and retail electronic payments in the 2000s. While these innovations have been shifting the balance in the financial system from banks towards markets and specialized players, the overall structure of the financial industry with banks at its core remained remarkably robust (Philippon 2015). ${ }^{3}$ In this paper, we argue that the ongoing changes are

\footnotetext{
${ }^{3}$ Over twenty-five years ago, Boyd and Gertler (1994) asked "Are Banks Dead? Or Are the Reports Greatly Exaggerated?" and concluded that the role of banks had in fact not diminished. Banks were neither driven to irrelevance by the disruption caused by the Global Financial Crisis.
} 
more fundamental than the previous ones, and may lead to deeper shifts in the financial industry structure.

To assess the implications of financial technology, we distinguish between the continuation of established trends (which may be accelerating) and genuinely new developments. To this end, we structure our discussion on the basis of the matrix depicted in Table 1. The first row summarizes the roles of information and communication for financial intermediation. The second and third rows indicate key technology-induced changes in each of those fields, distinguishing between what is old and what is new. Among the established trends, we highlight the proliferation of hard information and the change in financial sector communication from branch-based interaction to more distant links. Regarding new developments, the growth of the digital economy gives rise to new types of data, often nonfinancial in nature. The abundance of data in turn enables the use of big data analytics such as machine learning and artificial intelligence. Innovations in communication give rise to the dominance of digital platforms that take over an increasing share of customer communication.

Table 1. Technological progress and financial intermediation.

\begin{tabular}{|c|c|c|}
\hline & Information & Communication \\
\hline Role in financial intermediation & $\begin{array}{l}\text { Collect and process data for } \\
\text { screening and monitoring }\end{array}$ & $\begin{array}{l}\text { Establish relationships and } \\
\text { distribution networks }\end{array}$ \\
\hline Established Trends & Codification of soft information & $\begin{array}{l}\text { Move from in-person to distant } \\
\text { (telephone and online) } \\
\text { interactions }\end{array}$ \\
\hline New developments & $\begin{array}{l}\text { New types of (non-financial) } \\
\text { data; Data abundance enables } \\
\text { Al \& machine learning }\end{array}$ & $\begin{array}{l}\text { Low-cost search, matching, and } \\
\text { distribution through digital } \\
\text { platforms and mobile devices }\end{array}$ \\
\hline
\end{tabular}

\section{Information innovation: Established trends, amplified}

Innovations in the collection and processing of information have several dimensions. One is codification, which describes the conversion of soft information into hard information that can be processed and transmitted (Liberti and Petersen, 2018). Another is the emergence of vast non-financial data on consumer choices and preferences. The scale of these new data enables the use of analytical tools such as machine learning and artificial intelligence (AI) to deliver new insights, including for financial decision-making (Athey and Imbens, 2019; Philippon, 2020). More generally, the diffusion of the internet and advances in computing has led to a massive increase in the overall availability of data, often at negligible cost. 


\section{Established trends}

Much of the recent surge in information-related innovation in the financial industry can be seen as a continuation of past developments at an accelerated pace. The IT revolution of the 1990s boosted the ability to create and use hard information in finance. This gave rise to securitization, helped the proliferation of financial markets, increased financial sector competition, and induced bank consolidation. A well-established literature discusses the effects of hard information on financial intermediation. While it highlights the benefits in terms of access to finance, it also stresses a "dark side" of greater reliance on hard information.

On the positive side, hard information enables borrowers to obtain credit in larger volumes and at better terms. Credit scoring and information sharing via credit registries alleviate information-related frictions between borrowers and lenders (Jappelli and Pagano, 1993), which especially benefits riskier and more opaque borrowers (Berger and Frame, 2007). Moreover, the ability to securitize and sell loans insulates borrowers from lender financial conditions (Loutskina and Strahan, 2009), and decreases the cost of credit (Jaffee and Rosen, 1990; Jappelli and Pagano, 2002). More generally, there is evidence that IT-adoption helps banks to select better borrowers and thus increases their resilience in crisis times (Pierri and Timmer, 2020).

Despite these positive effects, the existing literature also highlights a "dark side" of hard information. Its use can worsen borrowing conditions for customers for which hard information is more difficult or impossible to generate, such as SMEs (Petersen and Rajan, 1994; Berger et al. 2005) or young and innovative firms (Dell'Ariccia et al., 2017).

Moreover, at the aggregate level, a financial system that relies on hard information can be more volatile. Banks that engage in soft information-based relationships with customers tend to smooth lending over the cycle, which helps to soften credit contractions in downturns (Allen and Gale, 1997; Bolton et al., 2016; Boot and Ratnovski, 2016). By contrast, hard information allows for the design of hard-powered managerial contracts that can encourage financial sector risk-seeking and myopia (Rajan, 2006).

Hard information enables securitization, which can be a double-edged sword. While securitization allows lenders to diversify or hedge risks, banks that target a certain risk profile can respond to these opportunities by weakening their lending standards (Keys et al., 2010; Loutskina and Strahan, 2011). Also, securitization has historically contributed to leverage-fire sale cycles (Lorenzoni, 2008; Stein, 2010; Gennaioli et al., 2013) and enabled regulatory arbitrage (Shin, 2009; Acharya et al., 2013). Relatedly, hard information favors large organizations (Stein, 2002), which induces consolidation in the financial system and thus may increase systemic risk (Berger et al., 2005; Laeven et al., 2016). Moreover, a 
proliferation of hard information can be used to price discriminate among customers (Shiller, 2013), and may amplify discrimination against minorities and socially disadvantaged groups due to statistical biases (Fuster et al., 2018). Finally, an increased availability of information can also undermine risk-sharing through the so-called "Hirshleifer effect", i.e., the destruction of risk-sharing possibilities through the revelation of information (Hirshleifer, 1971). ${ }^{4}$

\section{New developments}

Technological progress perpetuates the trend toward a greater use of hard information in finance, with both its benefits and drawbacks. As the volume of codified information increases, its use will expand from the current realm of standardized products such as mortgages into more complex business segments such as commercial lending and financial advisory services. While this will further increase efficiency and reduce costs, it can also amplify existing incentive problems or create new ones.

The use of non-financial data will have large effects on the provision of financial services. Traditionally, banks rely on the analysis of customer financial information from payment flows and accounting records. The rise of the internet permits the use of new types of nonfinancial customer data, such as browsing histories and online shopping behavior of individuals, or customer ratings for online vendors.

The literature suggests that such non-financial data are valuable for financial decision making. Berg et al. (2019) show that easy-to-collect information such as the so-called "digital footprint" (email provider, mobile carrier, operating system, etc.) performs as well as traditional credit scores in assessing borrower risk. Moreover, there are complementarities between financial and non-financial data: combining credit scores and digital footprint further improves loan default predictions. Accordingly, the incorporation of non-financial data can lead to significant efficiency gains in financial intermediation. ${ }^{5}$

Large technology firms collect vast amounts of non-financial data through their consumerfacing platforms in the areas of e-commerce, social networking, and online search. The sheer amount of data enables the use of "big data" analysis tools such as artificial intelligence and machine learning. The literature confirms their usefulness in finance. For example, Dobbie et

\footnotetext{
${ }^{4}$ See Section 8.3 in Vives (2010) for a discussion.

${ }^{5}$ While banks often do not have access to non-financial data, they also face regulatory uncertainty as to whether these data are allowed to be used for the provision of financial services.
} 
al. (2018) show that the use of machine learning can lead to significantly improved default risk predictions.

Accordingly, Bigtech firms have the informational capacity to compete, and possibly even outperform banks in financial service provision. This is corroborated by Frost et al. (2019), who show that the internal ratings of MercadoLibre, an online marketplace in Latin America, predict default risk better than credit scores. There is evidence that Bigtech finance is most effective when traditional financial intermediation is undersupplied. Hau et al. (2019) document that Ant Financial, an arm of the Alibaba online marketplace, extends more credit lines in rural areas of China with a limited presence of banks.

Finally, the proliferation of the internet increases the overall availability of public information; large amounts of data can be acquired at low cost via web-scraping. This reduces informational capture and increases the contestability of financial services. Accordingly, consumers and firms can reap a higher share of the surplus created by financial intermediation. In contrast, banks face pressure on revenues generated from acting as information providers for third parties. For example, buy-side investors have increased their reliance on "alternative data" such as satellite images, credit card sales, and mobile geolocation data. ${ }^{6}$ More widely available information also increases the efficiency of financial markets. ${ }^{7}$

These advantages come at the risk that hard information may become monopolized. Bigtech firms and other platforms may have privileged access to customer data, or their scale provides them with relative advantages in collecting and processing information. There is a tension between the private accumulation of data on the one hand and the increased public availability of data on the other hand. As pointed out by Hauswald and Marquez (2003), these two developments imply exactly the opposite for informational capture. Accordingly, the net effect of innovations in the collection and processing of information crucially depends on which of these two effects dominates.

\footnotetext{
${ }^{6}$ See "Asset managers double spending in new data in hunt for edge", Financial Times, May 9, 2018.

${ }^{7}$ Consistent with this argument, Gao and Huang (2020) document an increase of informational efficiency in the U.S. stock market following electronic dissemination of accounting information. More generally, Bai et al. (2016) document an increase in informational efficiency over time and attribute it to technology. However, Farboodi et al. (2020) show that this effect is driven by an increase in firm size, and show that prices have become less informative for smaller firms.
} 


\section{Communication innovation: Novel and increasingly pertinent}

The concept of "communication" refers to the establishment and maintenance of customer relationships as distribution channels for financial services. The finance literature has traditionally focused on the role of informational frictions in financial intermediation, because the effects related to communication are also present in non-financial industries and thus typically studied in the broader industrial organization literature. ${ }^{8}$ However, technological progress increases the importance of distribution channels in finance. We argue that, as a consequence, the role of communication in financial intermediation may in fact become more central than that of information.

\section{Established trends}

Historically, banks were local businesses that liaised with customers in a physical branch location. The associated spatial capture allowed banks to exert considerable market power. While early technological innovations, such as the ATM and telephone banking, increased convenience for customers and reduced costs for banks, banking largely remained a brickand-mortar business.

Communication started exerting a deeper influence on the structure of financial intermediation in the late 1990s and early 2000s, when the diffusion of the internet reached a critical mass and enabled the adoption of online banking, with increased process automation and deeper convenience benefits to customers. This enabled the entry of specialized players that focused on communication as a comparative advantage. In the market for deposits, it gave rise to direct banks that operated without a physical branch network and relied on thirdparty ATMs. In lending markets, independent mortgage originators offered faster credit approval relative to traditional banks. The new entrants competed with incumbent institutions on price and convenience, and were able to accumulate meaningful market shares. Interestingly, many such focused businesses were deeply affected by the global financial crisis of the 2008. Direct banks such as ING Direct suffered deposit outflows, while independent mortgage originators faced collapsing demand and losses on their pipeline.

Figure 2 illustrates the evolution from brick-and-mortar to online banking. The use of online banking services in the EU15 stood at only 19\% in the EU15 in 2003, but increased steadily

\footnotetext{
${ }^{8}$ One exception is the literature on financial networks, which focuses on the effects of financial sector network structure on financial stability (see Allen and Babus, 2009, for an overview). In contrast, we discuss how communication frictions affect the connectivity of financial intermediaries with their customers, with implications for competition and business models.
} 
to $59 \%$ in 2018 . In contrast, the number of branches declined drastically, from 540 branches per 1 million inhabitants in 1997 to only 331 in 2018.

Figure 2. Use of online banking and the number of bank branches in Europe.
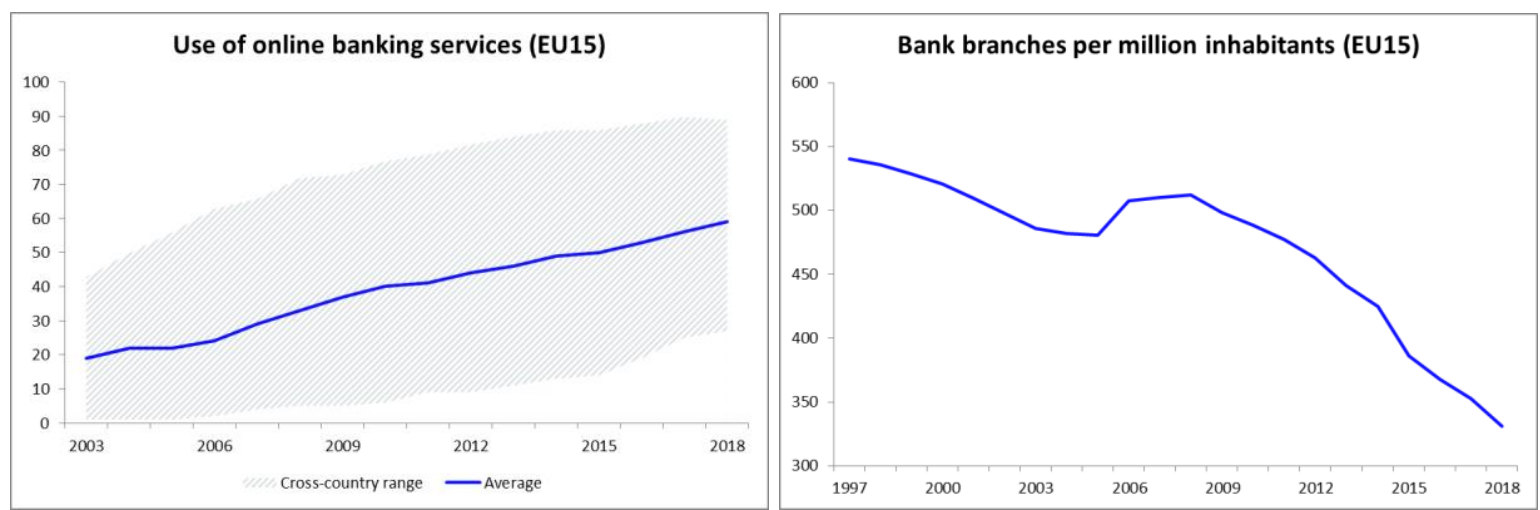

Note. The left Panel shows the share of survey responents that report regular use of online banking services. The blue line indicates the average, while the shaded grey area shows the cross-country range. Source: Eurostat. The right Panel graphs the number of bank branches per million inhabitants. Source: ECB Statistical Data Warehouse. All data cover EU 15 countries.

Moreover, innovation in communication sparked a trend towards bank consolidation that led to the creation of large universal banks and the repeal of the Glass-Steagall Act in 1999. At least in part, this development was fueled by banks' desire to reinforce their distribution networks (Houston et al., 2001), so as to strengthen their "first point of contact" advantages and the associated rents from cross-selling. Consolidation also enabled banks to reduce overhead and eliminate overcapacities associated with redundant geographically overlapping branches (Houston and Ryngaert, 1994).

\section{New developments}

There is little doubt that the days of brick-and-mortar banking - and the associated opportunities for cross-selling through a "first point of contact" advantage of branch banking - are largely over. Indeed, the number of bank branches in advanced economies is declining fast.

Today, new entrants can set up new and efficient communication channels via web portals and mobile apps at very low cost, and reach targeted audiences via direct marketing tools, including social media. Moreover, the ability to source IT infrastructure through cloud services considerably lowers the barriers to entry. Consistent with this, so-called "neo banks", such as Axos, Revolut, and N26, are challenging incumbents by offering customerfriendly interfaces and employing more efficient IT processes. In retail lending, the share of non-bank originators that compete on convenience has doubled from pre-crisis levels (Buchak et al., 2018). And in payments, new entrants such as Paypal, Adyen, and Stripe, 
specialize on facilitating payments for online purchases, and more broadly provide interconnections between payment systems in an increasingly globalized world. ${ }^{9}$ Many of the new entrants have accumulated a significant market share in the respective services, which suggests that competition in retail banking is likely to intensify in the future. ${ }^{10}$

The internet has also given rise to digital platforms as powerful intermediaries that consolidate information, match buyers and sellers, and enable peer-to-peer communication. Their nature as two-sided markets gives rise to significant network externalities, which limit contestability and favor few large players (Rochet and Tirole, 2003). ${ }^{11}$ Many of the underlying products and services have penetrated much of consumers' everyday lives, resulting in a very high "contact rate". Platform operators strive to provide an ever-increasing range of products and services in an attempt to generate spatial capture and become the "first point of contact" for a complete set of customer needs. ${ }^{12}$

Financial services fit well into digital ecosystems, both as standalone products (e.g. savings accounts) and through synergies with other goods and services offered on the platform (e.g. consumer credit in e-commerce). These synergies give platforms a strong communicationbased competitive advantage in financial service provision, especially because the consumption of financial services is typically not a motive in itself, but rather complements the ultimate consumption of non-financial goods or services. For example, consumers take mortgages to enable home ownership, and use payments to purchase goods and services, and do not derive utility from borrowing or transferring money in itself. ${ }^{13}$ Accordingly, digital platforms have a natural interest to include financial services into their offerings.

\footnotetext{
${ }^{9}$ While these entrants started their business as non-bank payments processors, some recently have acquired banking licenses (e.g. Adyen and Paypal).

${ }^{10}$ See "Race to become UK digital banking leader hots up", Financial Times, October 5, 2019.

${ }^{11}$ A product or service exhibits positive (negative) network externalities if its utility is increasing (decreasing) in the number of people consuming it. These effects can be direct or indirect. For example, social networks such as Facebook exhibit direct effects, since it is easier to find friends if more people sign up. Search engines such as Google display indirect effects: while users do not care about other users per se, increased usage improves the quality of search through more data. Finally, in two-sided markets, there can also be network effects across different sides. For example, consumers and merchants attract each other in online marketplaces.

12 In Asia, this development has culminated in the rise of so-called Super-Apps (WeChat, AliPay, Gojek, Grab) that offer a large variety of services (messaging, transportation, food delivery, entertainment) seamlessly through a single platform. See "Fintech: the rise of the Asian super app", Financial Times, December 13, 2019.

${ }^{13}$ A rare exception where financial services have their own utility is wealth management. But even here, wealth managers engage in bundling by offering access to "life style" products and services. See "People Over Products: Why Private Banks Should Focus On Relationships, Not Sales”, Forbes, May 5, 2020.
} 
Digital platforms also exhibit significant feedback effects between information and communication. Their communication advantage - their role as a first point of contactgives them abundant data on consumers and sellers, and thus also generates an informational advantage. Thus, platforms are able to exert both informational and spatial capture. For banks, these developments are challenging in two ways. One is the loss of the customer interface, and thus of their strong communication-based competitive advantage. The other is that specialized entrants now become more forceful competitors as they can easily distribute their services through platforms.

The final novel dimension of platforms is that their overwhelming market power over distribution channels gives them an advantage over banks at enforcement. The threat to exclude customers after missing credit repayments may weigh heavily, especially in weaker institutional environments.

\section{The future of banks}

The rapid pace of technological progress raises questions about the future of banks. Banks typically are vertically and horizontally integrated financial intermediaries. In vertical terms, they use their balance sheet to perform maturity transformation, and directly interact with customers when raising deposits and making loans. Horizontally, banks provide services that do not directly rely on a balance sheet, but have informational or communication synergies with deposit-taking or loan-granting. For example, payment information can help monitor loans (Puri et al., 2017; Parlour et al., 2019), information from lending can assist underwriting (Kroszner and Rajan, 1994; Drucker and Puri, 2005), and established communication channels with retail depositors enable the cross-selling of savings or insurance products, which boosts bank revenues and helping income diversification (Stiroh and Rumble, 2006).

Innovations in information and communication pose two fundamental challenges for the integrated bank business model. First, they enable the entry of specialized competitors with a focus on financial services that require little or no access to a balance sheet, thus challenging banks' horizontal integration. Second, digital platforms compete with banks for direct access to customers, thus challenging banks' vertical integration. We discuss these challenges in turn.

\section{Challenge 1: Horizontal disintegration through specialized competitors}

Aside from their core maturity transformation business, banks provide a wide range of services where they act as agents or brokers. In this case, they take on little or no risk, and 
collect fees for providing services. The most prominent activities of this type are asset and wealth management, insurance, brokerage, advisory services, and payments.

Historically, banks' position as a first point-of-contact for financial services enabled them to capture rents through the cross-selling of their own or third-party products. For example, the asset management industry in Europe and Japan is still dominated by banks, despite their underperformance compared to non-bank providers of similar services (Ferreira et al., 2018).

Since horizontally integrated banking services require no access to a deep balance sheet, they can also be performed by non-banks. Novel distribution channels diminish banks' position as gatekeepers to financial services, and enable specialized providers to gain direct access to customers. These specialized entrants can avoid the organizational inefficiencies present in large banks (Scharfstein and Stein, 2000), which helps them to be agile and efficient in their use of technology. Consequently, they may be able to beat banks on price, speed, and convenience (Fuster et al., 2019).

In addition to technological drivers, the horizontal disintegration of financial services is also facilitated by regulation. Offering specialized financial services often does not require a full banking license. For example, several jurisdictions now grant licenses for the provision of electronic payment services. This lowers the regulatory compliance costs of specialized entrants.

The communication-driven horizontal disintegration of financial service provision is different from past experiences that were information-driven. The rise of hard information in the 1990s enabled independent mortgage originators, which used ratings-based certification to securitize and sell mortgage exposures to end-investors. The originate-to-distribute model was associated with well-known incentive problems, driven by moral hazard and adverse selection. Since the current disintegration is driven by communication, it is less impeded by information frictions, and can induce deeper structural changes in financial service provision.

\section{Challenge 2: Re-intermediation through platforms}

The rise of digital platforms fundamentally changes the way goods and services are distributed. Consumer choice was historically constrained by significant search costs. These have now dropped to near zero: prices and features of most goods and services can be compared with a few clicks or swipes. Network externalities inherent in two-sided markets lead to the dominance of a few large platforms competing for users' attention. To strengthen lock-in effects and maximize data generation, platforms are offering an ever-expanding range of products and services. The inclusion of financial services would naturally complement most platforms' business model. Since platforms may become middlemen between 
customers and financial institutions, their entry will introduce an additional layer of intermediation that can be labelled "re-intermediation".

While consumers are likely to embrace the integration of financial services into digital ecosystems, such a transition poses a severe threat to banks. When online platforms interject themselves between banks and customers, they introduce another layer of intermediation that captures most of the existing rents, and much of customer data. As a consequence, banks can lose direct access to their customers and face the risk of vertical disintegration.

The most potent digital platforms are the ecosystems of Bigtech firms, which can leverage upon a large customer base from their non-financial core activities that allows them to exert market power. They also have access to vast amounts of customer data to support their venture into finance. Another type of platforms is price comparison sites for financial products such as mortgages and deposits. The absence of an established "outside" business means that they need to grow quickly in order to reach the critical mass required to become a "gatekeeper" for customer access. ${ }^{14}$ Once successful, however, financial comparison sites may morph into "financial supermarkets" - specialized online platforms that offer access to the full range of financial services. ${ }^{15}$

Importantly, platforms do not need to provide financial services themselves: they can monetize their comparative advantages without maintaining a dedicated balance sheet. On the communication side, the platforms' activity can be viewed as "match-making", which does not require risk-taking. On the information side, customer data can be passed on to other financial service providers. The recently announced partnerships between Apple and Goldman Sachs as well as Google and Citigroup are consistent with this view, and most likely only mark the beginning of Bigtech platform involvement in financial services provision. ${ }^{16}$ Importantly, such partnerships need not stay exclusive over time, as platforms may prefer to create competition among several participating banks to maximize their own rents. In addition, digital platforms also enable specialized financial players to distribute their products more widely. This means that the vertical disintegration of the bank business model amplifies its horizontal disintegration. Not providing financial services directly also allows platforms avoid compliance costs, and, especially in the case of Bigtech firms, political resistance.

\footnotetext{
${ }^{14}$ Formally, comparison sites cannot engage in "platform envelopment", see Eisenmann et al. (2011).

15 Prominent examples in this direction include Check24 (Germany) and BankBazaar(India).

16 See "Apple Debuts Titanium Credit Card With Goldman, Mastercard", Bloomberg, March 25, 2019, and "Google Makes a Bid for Banking, Where Tech Firms Go to Stumble”, New York Times, November 13, 2019.
} 
The involvement of non-financial firms in the provision of financial services is not novel per se. Historically, large manufacturers have facilitated trade credit, loans for consumer durables, project finance, and leasing. Yet, the scope of their involvement was typically bounded by the limited range of circumstances in which they had a comparative advantage over banks in terms of information or communication. ${ }^{17}$ The rise of digital platforms may change this fundamentally, since Bigtech firms offer a vast range of products and services, and at the same time appear to have an edge over banks in both communication and information.

\section{Limiting factors and banks' response}

Based on the two challenges outlined above, the future of banks may appear bleak. In the extreme, digital platforms and specialized competitors can induce a complete vertical and horizontal disintegration of the traditional bank business model. In this case, banks will be relegated to the role of upstream (noncustomer-facing) suppliers of maturity transformation services, while downstream (customer-facing) services will be taken over by platforms and specialized providers. Yet, there are a number of limiting factors to this extreme outcome.

First, banks will aim to improve their capabilities in communication and in information processing through massive IT investment. This involves upgrading outdated systems and processes, unifying geographically segmented systems, shifting to cloud computing, and developing new, digital-oriented financial products and services that match customer needs (such as new customer interfaces and significantly faster credit decision systems). Banks may also acquire or cooperate with specialized Fintech firms in order to procure expertise for the digitalization of key processes.

However, the organizational complexity of large banks will complicate the transition. Moreover, banks may be slow in adapting new technologies due to higher (perceived) reputational risks relative to new entrants. This can be amplified by uncertainty about the regulatory stance, and a lack of regulatory guidelines regarding the use of new digital tools. Finally, low profitability and labor market frictions can prevent the required swift changes, especially in Europe.

\footnotetext{
${ }^{17}$ For example, trade credit can serve as a monitoring tool for suppliers (Smith, 1987). Similarly, specialized firms can be more efficient than banks at re-deploying repossessed assets (Mian and Smith, 1992; Habib and Johnsen, 1999) or assessing collateral values (Brennan et al., 1998; Stroebl, 2016). Petersen and Rajan (1997) argue that critical suppliers have a superior enforcement capability if they can threaten to disrupt a borrower's business continuity in response to non-payments. The provision of financing also enables producers to increase product demand via cross-subsidization of lending and sales (Banner, 1958; Barron, Chong, and Staten, 2008).
} 
The most digitally ambitious banks may try to develop their own platform-based ecosystems as a means of staying competitive. To this end, they can enrich their core service offering with complementary financial and non-financial services. For example, banks may offer alternative lending arrangements (e.g., P2P) for riskier customers, or integrate real estate agent services into their mortgage lending business. However, such changes would challenge banks to leave their narrow realm of expertise and be open to changing their overall business model.

A second limiting factor to the disintegration of bank business models are limits to the reach of digital platforms. Bigtech firms and price comparison sites are mainly focused on retail consumers. While this enables them to distribute retail financial services such as payments and consumer loans, as well as SME loans for online merchants, banks may - at least for now-be able to maintain their competitive advantage in serving corporate clients.

This may change, however, with the fast-growing adoption of cloud computing. Bigtech firms that provide such services - Amazon, Microsoft, Google, and Alibaba — are establishing communication channels with a wide range of corporate clients, including very large firms and the public sector. They may then be able to develop broader ecosystems around their cloud services, including business-to-business (B2B) marketplaces that would also supply financial services. High contact rates and potential access to non-financial information on corporate customers would enable the providers of cloud services to rival banks' information and communication advantages in the corporate segment.

A third limiting factor is that banks may succeed in preserving the integrated provision of financial service for their most information-intensive customers. This may lead to the revival of merchant banks - "trusted advisors" that provide tailored solutions for corporate customers with complex needs. Technological innovation may in fact foster standalone merchant banking, since it becomes easier to source services and infrastructures that were previously shared within financial conglomerates, such as hedging, funding, compliance, and IT. A re-emergence of merchant banking would be consistent with the long-held view in the literature that relationship banking can survive competition by increasing its relationship intensity (Boot and Thakor, 2000).

Finally, policy and regulation will matter. While the question of which financial industry structure is optimal is difficult to answer, policy should aim to correct apparent market failures. As we discuss in the next section, key policy objectives are to ensure a level playing field in prudential regulation and to address the natural monopoly features of platforms in communication and data access. Without any policy intervention (in a "laissez-faire" environment), loosely regulated entrants could crowd out banks even when the integrated bank business model may be optimal. 


\section{Policy challenges}

Innovation in information and communication, and the consequent shift in the financial industry structure from banks to specialized entrants and digital platforms create novel challenges for public policy. Below we list a number of priorities across various domains. The key risk throughout is that policymakers fall behind the curve by protecting outdated business models, having no structured approach vis-à-vis the new entrants, and not being ready to deal with new technologies. ${ }^{18}$ Network effects may give rise to tipping points with rapid changes and costly ex-post adjustment. Moreover, the scale of potential entrants particularly Bigtech firms - will enable them to accumulate political power. Note that the question of whether other entities can efficiently fulfil the economic role of banks remains open. However, even if this were the case, the transition will be complex and require fundamental adjustments by policymakers because banks are currently at the core of monetary and macroprudential policies.

\section{Prudential policy: New dimensions}

Prudential regulation corrects excessive financial risk-taking. Micro-prudential regulation addresses risks driven by leverage and focuses on individual firms (Dewatripont and Tirole, 1994). Macro-prudential regulation corrects for externalities, and focuses on the system as a whole (De Nicolo et al., 2012). New technologies will challenge prudential regulation on several dimensions.

First, a financial system more reliant on hard information is more cyclical and crisis-prone (see Section 3). In addition, the robustness of new lending technologies (such as P2P or those based on digital footprint data) is untested in downturns. If banks lose retail deposits and shift to flighty wholesale funding (such as brokered deposits), the whole financial system would become more susceptible to liquidity freezes - as the 2008 crisis has abundantly illustrated. Further, new and rapidly changing business models and processes pose operational risks that may be hard to monitor and quantify. ${ }^{19}$

Second, the disintermediation of financial supply chains creates regulatory arbitrage concerns. Risks can become "hidden" in complex network structures, placed in less regulated

\footnotetext{
18 This also points at transition issues that supervisors and policymakers need to be aware of. These do not just involve understanding new technologies and players (and the associated trial \& error), but also anticipating and understanding the problems faced by incumbents when adjusting to the new competitive realities.

19 The recent failure of Wirecard, a German payment processor, illustrates the difficulty of critically assessing new business models.
} 
entities or more lenient jurisdictions. Establishing a level playing field across entities ${ }^{20}$ and avoiding a race-to-the bottom across jurisdictions becomes paramount. At the same time, concerns about regulatory arbitrage concerns must be balanced with the scope for experimentation, including the use of regulatory "sandboxes" for innovative firms and the use of novel data-driven supervisory methods ("regtech").

Third, the concept of systemically important financial institutions and infrastructures widens. Platforms engaged in financial service provision are likely to become systemically important. Large providers of cloud services may need to be designated as systemically important infrastructures. Yet, such designation for non-bank - let alone non-financial—-firms has often been politically difficult in the past. $^{21}$

Finally, regulatory agencies must keep track with innovation and its outcomes. They will need to adjust more rapidly to new business processes and a less bank-centric financial industry structure. Legacy banks should be guided to adjust in a forward-looking manner, through restructuring, consolidation, or exit. ${ }^{22}$ Regulators also need to respond to the use of new types of data and new data analysis tools in financial services. AI and machine learning pose distinct regulatory challenges because they have no underlying models, so their results can be difficult to interpret, extrapolate to stressed scenarios, or cross-validate. Prudential policy will have to monitor cyber security risks, as well as novel prudential risks driven by the interlinkages between the financial and non-financial activities of platforms and cloud providers. ${ }^{23}$ Critically, regulatory agencies have historically struggled to ensure that their expertise matches that of the industry (Hakenes and Schnabel, 2014). This may become even harder as innovation intensifies, and more talent enters the financial technology sphere. Ensuring expertise is critical not only for quality supervision and regulation, but also to ensure that regulators can guide the social debate on the innovation-stability trade-off, fending off pressures for unbridled innovation as the memories of past financial crises fade.

\footnotetext{
${ }^{20}$ Early evidence suggests that prudential regulation can be effective in creating a more even playing field between banks and Bigtech firms. Claessens et al. (2018) show that Bigtech firms play a less prominent role in financial services provision in countries with more stringent prudential regulation. See also Berger and Udell (2006) on the impact of public policy on the financial industry structure.

${ }^{21}$ See e.g. "MetLife Defeats U.S. Government's Too-Big-to-Fail Labeling”, Bloomberg, March 30, 2016.

22 To ensure continued viability of legacy banks, supervisors may need to collect different data than in the past, including information on IT investments, customer contact channels, etc.

${ }^{23}$ See https://www.cnbc.com/2019/10/24/senators-urge-investigation-of-amazons-role-in-capital-one-hack.html
} 


\section{Monetary policy: A new environment}

The changes in the structure of the financial industry induced by technology will affect monetary policy transmission and implementation. Information and communication innovations render deposit and loan markets more contestable, which will likely amplify the pass-through of policy rates to lending conditions and deposit rates (e.g. Drechsler et al. 2017, 2018). As the importance of bank lending diminishes (e.g. because it is replaced by non-bank or P2P lending), so might the importance of bank capital and financing conditions for monetary policy transmission (Van den Heuvel, 2002). The introduction of central bank digital currencies (CBDCs) - also in response to payment innovations - may make monetary policy transmission more direct, and remove the effective lower bound on interest rates (Bordo and Levin, 2017). ${ }^{24} \mathrm{~A}$ better pass-through might be welcome, as a more cyclical and hard information-based financial system may require more countercyclical monetary policy.

In monetary policy implementation, the increased use of collateral enabled by the proliferation of hard information will further weaken the importance of unsecured funding markets. This, and the diminishing role of banks, will make unsecured interbank interest rates a less effective operational target (English, 2002), and call for benchmarks based on secured transactions among a wide set of market participants. Also, the decreasing number and importance of bank counterparties for central bank operations will spark further debate on allowing non-banks to access central bank reserves.

\section{Competition policy: Platforms as natural monopolies for communication and data}

The "first point of contact" advantages of digital platforms give rise to natural monopolies in communication and data collection. ${ }^{25}$ Competition policy should balance platforms' incentives to invest with outsiders' ability to access their communication infrastructure and data pools. Recent national regulation in Germany provides an example of policy towards natural monopolies in communication in the context of financial services provision. Starting in 2020, new legislation mandated, on competition grounds, that Apple should open the iPhone's near-field communication (NFC) port to third party payment providers, enabling them to compete with the company's "Apple Pay" service. ${ }^{26}$ This represents, however, a one-

\footnotetext{
${ }^{24}$ See Griffoli et al. (2018) for a more extensive discussion of CBDC design choices, and of the relationship between CBDC and monetary policy pass-through.

25 The fact that platforms are two-sided markets with strong network externalities renders many standard models of antitrust inappropriate, and regulators continue to struggle with this new environment. See Evans and Schmalensee (2015) for the analysis of antitrust issues in two-sided platforms.

26 “Apple warns of risks from German law to open up mobile payments", Reuters, 16 October 2019.
} 
off solution and a more holistic policy dealing with the natural monopoly aspects of platforms is more appropriate.

\section{Public standards and infrastructures: Focus on data and interconnections}

Standardization and infrastructure are public goods. Private markets can converge on suboptimal information sharing and communication protocols that may become entrenched due to network effects, giving rise to inefficiencies and rents. ${ }^{27}$ Public policy can help market participants coordinate on better standards. Innovations in information and communication give rise to two areas where standardization is needed: data treatment and exchange, and communication protocols.

Data is crucial for financial services provision: it helps manage risks and overcome adverse selection. This is beyond its role in non-financial services, where it is mainly used for targeting customers with product offerings. The scope for market failures in the collection, protection, use, and exchange of data is large. Data ownership rules are often undefined; the use of data is non-rivalrous, but exhibits large economies of scale and scope especially under AI and big data; data collection can entail externalities (Garratt and van Oordt, 2019) and display natural monopoly properties when done by platforms. Public policy should consider standards in the areas of data ownership, maintenance, and exchange - including the templates to classify data (and thus assign ownership) and to standardize data (and thus enable its efficient exchange). Repositories for data generated by platforms and other nonbank financial services providers (similar to traditional credit registries) or data price regulation can be part of a solution.

The increasing use of private data for financial services also raises a myriad of consumer protection and privacy issues that require the government to set standards for data collection and use. International data standards are needed, to balance data protection within jurisdictions with the benefits of their cross-border use. The public debate on the efficiencyprivacy trade-off in financial services provision (the "society of the future" debate) is not advanced enough yet to converge on desirable outcomes. For example, fair lending rules such as the Equal Credit Opportunity Act and the Fair Housing Act in the United States ban the use of certain data (e.g., on gender or race) for making lending or insurance decisions,

\footnotetext{
${ }^{27}$ Competition between two standards is often referred to as a "standard war". More efficient standards do not necessarily end up dominating the market. For example, in the $19^{\text {th }}$ century more cost-efficient alternative current has replaced Edison's direct current. At the same time, a more ergonomic Dvorak keyboard has never been able to replace the entrenched QWERTY standard.
} 
primarily to avoid discrimination. Bigtech firms face no similar "equal opportunity"-related restrictions. ${ }^{28}$

There is also a need for level playing field in data standards between banks and non-banks. Banks are subject to stringent data privacy requirements, which their competitors often do not face. And while "open banking" initiatives such as PSD2 make bank information available to third parties, no similar information sharing requirement is imposed on non-bank financial service providers.

Communication innovation and the disintegration of financial services value chains imply much larger demand for connectivity. It is this demand that is already pushing authorities to strengthen existing infrastructures in payment systems. Authorities also have a key role to play in creating a system of digital identities that helps households and firms operate in a digital economy, including within the financial sector. ${ }^{29}$ Standardization protocols and public infrastructure need to also support cross-border interconnections, an aspect especially important in the EU single market.

\section{Conclusions}

This paper provides an overview of the effects of recent innovations in information (data collection and processing) and communication (distribution and connectivity) on the structure of financial intermediation. We have argued that information-related innovation follows past trends such as credit scoring and securitization. The key new development is the abundance of non-financial data, including from digital footprints, which can be used in financial services provision. Thanks to large volumes, these data can be analyzed using machine learning and artificial intelligence, which gives rise to economies of scale in data usage and thus benefits large technology firms and other platform intermediaries. While the role of communication has been studied less extensively in the existing literature, we argue that recent innovations render communication advantages a key competitive factor in financial services by reducing barriers to entry and weakening banks' traditional role as the "first point of contact" for financial services. New distribution channels enable the entry of specialized financial service providers with a focus on activities that do not require access to deep balance sheets, such as payments and asset management. Furthermore, it allows digital

\footnotetext{
${ }^{28}$ Policy-making is complicated by the fact that the economics of data is a nascent field (see Carrière-Swallow and Haksar, 2019, for a review).

${ }^{29}$ The "India Stack" initiative is a prime example in this direction. Also, authorities need to ensure that those lacking digital literacy (e.g. the elderly or the socio-economically disadvantaged) do not suffer severe limitations on their access to finance as a consequence of technological progress.
} 
platforms to include financial services into their ecosystems to further reduce search and connectivity costs.

These developments pose a formidable challenge to the traditional business model of universal banking, which is based on horizontally and vertically integrated financial service provision. Specialized service providers can chip off the most lucrative vertically integrated services, while platforms can take over communication with savers and borrowers, leading also to vertical disintegration of financial value chains. In the extreme case, this trend can relegate banks to upstream providers of maturity transformation services. While digital platforms' focus on retail customers and SMEs limits their reach, the increasing relevance of cloud computing services enables large technology firms to directly engage with large corporate clients, and thus compete with banks in financial services provision to this clientele as well.

We discuss a number of public policy priorities related to innovations in information and communication that demand a number of public policy priorities. Prudential regulation will be challenged in responding to new technologies in banking. Monetary policy will need to operate through a wider set of counterparties and in an environment of a more cyclical financial system. And competition policy, data regulation and the provision of public standards will have key roles to play in ensuring optimal market outcomes.

Technological change is a medium-term process. Yet external shocks - such as the ongoing COVID-19 crisis - can make the adoption of financial innovation more rapid, and amplify its effects on the financial industry structure. Digital platforms may strengthen their market position thanks to higher demand for digital services, and leverage upon their balance sheet strength to penetrate new markets more easily. In contrast, banks may have to prioritize crisis management and postpone investment in digital transformation. Prudential regulators may be softer in responding to medium-term prudential risks, including those from new technologydriven entrants, as they focus on restarting lending. In this context, the ongoing COVID-19 crisis makes the response to information and communication innovation in finance an even more urgent policy priority. 


\section{References}

Acharya, V.V., Schnabl, P. and Suarez, G. (2013), "Securitization without risk transfer", Journal of Financial Economics, No 107(3), pp. 515-536.

Agarwal, S. and Hauswald, R. (2010), "Distance and private information in lending”, Review of Financial Studies, No 23(7), pp. 2757-2788.

Allen, F. and Babus, A. (2009), "Networks in finance", The network challenge: strategy, profit, and risk in an interlinked world, No 367.

Allen, F. and Gale, D. (1997), "Financial markets, intermediaries, and intertemporal smoothing“, Journal of Political Economy, No 105(3), pp. 523-546.

Armstrong, M. and Vickers, J. (2019), "Discriminating against captive customers", American Economic Review: Insights, No 1(3), pp. 257-72.

Athey, S. and Imbens, G.W. (2019), "Machine learning methods that economists should know about", Annual Review of Economics, No 11, pp. 685-725.

Bai, J., Philippon, T., and Savov, A. (2016). "Have financial markets become more informative?” Journal of Financial Economics, 122(3), pp. 625-654.

Banner, P.H. (1958), "Competition, credit policies, and the captive finance company", Quarterly Journal of Economics, No 72(2), pp. 241-258.

Barron, J.M., Chong, B.U. and Staten, M.E. (2008), "Emergence of captive finance companies and risk segmentation in loan markets: theory and evidence", Journal of Money, Credit and Banking, No 40(1), pp. 173-192.

Berg, T., Burg, V., Gombović, A., and Puri, M. (2019). "On the rise of fintechs: credit scoring using digital footprints." Review of Financial Studies, forthcoming.

Berger, A.N. and Frame, W.S. (2007), "Small business credit scoring and credit availability", Journal of small business management, No 45(1), pp. 5-22.

Berger, A.N. and Udell, G.F. (2006), "A more complete conceptual framework for SME finance”, Journal of Banking \& Finance, No 30(11), pp. 2945-2966.

Berger, A.N., Miller, N.H., Petersen, M.A., Rajan, R.G. and Stein, J.C. (2005), "Does function follow organizational form? Evidence from the lending practices of large and small banks", Journal of Financial economics, No 76(2), pp. 237-269. 
Bolton, P., Freixas, X., Gambacorta, L., and Mistrulli, P.E. (2016), "Relationship and transaction lending in a crisis", Review of Financial Studies, No 29(10), pp. 26432676.

Boot, A.W. (2000), "Relationship banking: What do we know?”, Journal of Financial Intermediation, No 9, pp. 7-25.

Boot, A.W., Greenbaum, S.I., and Thakor, A.V. (1993).. "Reputation and discretion in financial contracting." American Economic Review, 83(5), pp. 1165-1183.

Boot, A.W. and Ratnovski, L. (2016), "Banking and trading”, Review of Finance, No 20(6), pp. 2219-2246.

Boot, A. W., \& Thakor, A. V. (2000). "Can relationship banking survive competition?” Journal of Finance, No 55(2), pp. 679-713.

Bordo, M.D. and Levin, A.T. (2017), "Central bank digital currency and the future of monetary policy", National Bureau of Economic Research Working Paper, No 23711.

Boyd, J.H. and Gertler, M. (1994), “Are banks dead?”, The Region, No Sep, pp. 22-26.

Brennan, M.J., Maksimovic, V. and Zechner, J. (1988), "Vendor financing”, Journal of Finance, No 43(5), pp. 1127-1141.

Buchak, G., Matvos, G., Piskorski, T. and Seru, A. (2018), "Fintech, regulatory arbitrage, and the rise of shadow banks", Journal of Financial Economics, No 130(3), pp. 453483.

Carrière-Swallow, M.Y., and Haksar, M.V. (2019), "The Economics and Implications of Data: An Integrated Perspective”, International Monetary Fund, No WP/19/16.

Claessens, S., Frost, J., Turner, G. and Zhu, F. (2018), "Fintech credit markets around the world: size, drivers and policy issues", BIS Quarterly Review September.

De Nicoló, M.G., Favara, G. and Ratnovski, L. (2012), "Externalities and macroprudential policy", IMF Staff Discussion Note, No SDN/12/05.

Degryse, H. and Ongena, S. (2005), “Distance, lending relationships, and competition”, Journal of Finance, No 60(1), pp. 231-266.

Dell'Ariccia, M.G., Kadyrzhanova, D., Minoiu, M.C. and Ratnovski, M. L. (2017), "Bank lending in the knowledge economy", IMF Working Paper, No WP/17/234.

Dewatripont, M., and Tirole, J. (1994), The prudential regulation of banks. MIT Press. 
Diamond, D.W. (1984), "Financial intermediation and delegated monitoring", Review of Economic Studies, No 51(3), pp. 393-414.

Dobbie, W., Liberman, A., Paravisini, D. and Pathania, V. (2018), "Measuring bias in consumer lending", National Bureau of Economic Research Working Paper, No 24953.

Drechsler, I., Savov, A., and Schnabl, P. (2017). "The deposits channel of monetary policy". Quarterly Journal of Economics, No 132(4), pp. 1819-1876.

Drechsler, I., Savov, A., and Schnabl, P. (2018). "Banking on deposits: Maturity transformation without interest rate risk." National Bureau of Economic Research Working Paper 24582.

Drucker, S., and Puri, M. (2005). "On the benefits of concurrent lending and underwriting." Journal of Finance, No 60(6), pp. 2763-2799.

Eisenmann, T., Parker, G. and Van Alstyne, M. (2011), "Platform envelopment”, Strategic Management Journal, No 32, pp. 1270-1285.

English, W. B. (2002). Financial consolidation and monetary policy. FRBNY Economic Policy Review, 8(1).

Evans, D.S. and Schmalensee, R. (2015), "The antitrust analysis of multi-sided platform businesses", The Oxford Handbook of International Antitrust Economics, No 1.

Farboodi, M., Matray, A., Veldkamp, L., and Venkateswaran, V. (2020). Where has all the data gone? National Bureau of Economic Research Working Paper 26927.

Ferreira, M.A., Matos, P. and Pires, P. (2018), "Asset management within commercial banking groups: International evidence”, Journal of Finance, No 73(5), pp. 21812227.

Frost, J., Gambacorta, L., Huang, Y., Shin, H. S., and Zbinden, P. (2019). "BigTech and the changing structure of financial intermediation”. BIS Working Paper 779.

Fuster, A., Goldsmith-Pinkham, P., Ramadorai, T. and Walther, A. (2018), "Predictably unequal? The effects of machine learning on credit markets", Working Paper.

Fuster, A., Plosser, M., Schnabl, P. and Vickery, J. (2019), "The role of technology in mortgage lending", Review of Financial Studies, No 32(5), pp. 1854-1899.

Gao, M., \& Huang, J. (2020). "Informing the market: The effect of modern information technologies on information production.” Review of Financial Studies, 33(4), pp. 1367-1411.

(CInternational Monetary Fund. Not for Redistribution 
Garratt, R. and Van Oordt, M. R. (2019), "Privacy as a public good: a case for electronic cash", Bank of Canada Staff Working Paper, No 2019-24.

Gennaioli, N., Shleifer, A. and Vishny, R.W. (2013), “A model of shadow banking”, Journal of Finance, No 68(4), pp. 1331-1363.

Griffoli, M.T.M., Peria M.M.S.M., Agur, M.I., Ari, M.A., Kiff, M.J., Popescu, M.A. and Rochon, M.C. (2018), "Casting light on central bank digital currencies”, IMF Staff Discussion Note, No SDN/18/08.

Habib, M.A. and Johnsen, D.B. (1999), "The financing and redeployment of specific assets", The Journal of Finance, No 54(2), pp. 693-720.

Hakenes, H. and Schnabel, I. (2014), "Regulatory capture by sophistication”, Mimeo. University of Bonn.

Hau, H., Huang, Y., Shan, H. and Sheng, Z. (2019), "How fintech enters China's credit market", AEA Papers and Proceedings, No 109, pp. 60-64.

Hauswald, R. and Marquez, R. (2003), "Information technology and financial services competition", The Review of Financial Studies, No 16(3), pp. 921-948.

Hirshleifer, J. (1971), "The private and social value of information and the reward to inventive activity", The American Economic Review, No 61(4), pp. 561-574.

Holmstrom B. and Tirole, J. (1997), "Financial intermediation, loanable funds, and the real sector”, The Quarterly Journal of Economics, No 112(3), pp. 663-691.

Houston, J.F. and Ryngaert, M. D. (1994), “The overall gains from large bank mergers", Journal of Banking \& Finance, No 18(6), pp. 1155-1176.

Houston, J.F., James, C.M. and Ryngaert, M.D. (2001), "Where do merger gains come from? Bank mergers from the perspective of insiders and outsiders", Journal of Financial Economics, No 60(2-3), pp. 285-331.

Jaffee, D.M. and Rosen, K. T. (1990), "Mortgage securitization trends", Journal of Housing Research, No 1(1), pp. 117-137.

Jappelli, T. and Pagano, M. (2002), "Information sharing, lending and defaults: Crosscountry evidence", Journal of Banking \& Finance, No 26(10), pp. 2017-2045.

Keys, B. J., Mukherjee, T., Seru, A. and Vig, V. (2010), “Did securitization lead to lax screening? Evidence from subprime loans", Quarterly Journal of Economics, No 125(1), pp. 307-362. 
Kroszner, R.S. and Rajan, R.G. (1994), "Is the Glass-Steagall Act justified? A study of the US experience with universal banking before 1933", American Economic Review, pp. 810-832.

Laeven, L., Ratnovski, L. and Tong, H. (2016), "Bank size, capital, and systemic risk: Some international evidence", Journal of Banking \& Finance, No 69, pp. S25-S34.

Liberti, J.M. and Petersen, M.A. (2018), "Information: Hard and soft", Review of Corporate Finance Studies, No 8(1), pp. 1-41.

López-Espinosa, G., Mayordomo, S. and Moreno, A. (2017), “When does relationship lending start to pay?", Journal of Financial Intermediation, No 31, pp.16-29.

Lorenzoni, G. (2008), "Inefficient credit booms", Review of Economic Studies, No 75(3), pp. 809-833.

Loutskina, E. and Strahan, P. E. (2009), "Securitization and the declining impact of bank finance on loan supply: Evidence from mortgage originations", Journal of Finance, No 64(2), pp. 861-889.

Loutskina, E. and Strahan, P.E. (2011), "Informed and uninformed investment in housing: The downside of diversification", Review of Financial Studies, No 24(5), pp. 14471480.

Mian, S. L. and Smith Jr, C.W. (1992), “Accounts receivable management policy: theory and evidence”, Journal of Finance, No 47(1), pp. 169-200.

Pagano, M. and Jappelli, T. (1993), "Information sharing in credit markets", The Journal of Finance, No 48(5), pp.1693-1718.

Parlour, C. A., Rajan, U. and Zhu, H. (2019), "Fintech Disruption, Payment Data, and Bank Information", Mimeo.

Petersen, M.A. and Rajan, R.G. (1994), “The benefits of lending relationships: Evidence from small business data", Journal of Finance, No 49(1), pp. 3-37.

Petersen, M. A. and Rajan, R.G. (1995), "The effect of credit market competition on lending relationships", The Quarterly Journal of Economics, No 110(2), pp. 407-443.

Petersen, M. A., and Rajan, R. G. (1997), "Trade credit: theories and evidence", Review of Financial Studies, No 10(3), pp. 661-691.

Petralia, K., Philippon, T., Rice, T., \& Veron, N. (2019). "Banking disrupted. Financial intermediation in an era of transformational technology", Geneva Report on the World Economy, 22. 
Pierri, N. and Timmer, Y. (2020), "Tech in fin before fintech: Blessing or curse for financial stability?", IMF Working Paper, WP20/14.

Philippon, T. (2015). "Has the US finance industry become less efficient? On the theory and measurement of financial intermediation", American Economic Review, No 105(4), pp. 1408-38.

Philippon, T. (2020), “On fintech and financial inclusion”, BIS Working Papers, No 841.

Puri, M. and Rocholl, J. (2008), "On the importance of retail banking relationships", Journal of Financial Economics, No 89(2), pp. 253-267.

Puri, M., Rocholl, J. and Steffen, S. (2017), "What do a million observations have to say about loan defaults? Opening the black box of relationships", Journal of Financial Intermediation, No 31, pp. 1-15.

Rajan, R.G. (1992), "Insiders and outsiders: The choice between informed and arm's-length debt", The Journal of Finance, No 47(4), pp. 1367-1400.

Rajan, R.G. (2006), “Has finance made the world riskier?”, European Financial Management, No 12(4), pp. 499-533.

Rochet, J. C. and Tirole, J. (2003), "Platform competition in two-sided markets", Journal of the European Economic Association, No 1(4), pp. 990-1029.

Scharfstein, D. S., and Stein, J. C. (2000). "The dark side of internal capital markets: Divisional rent-seeking and inefficient investment", Journal of Finance, No 55(6), pp. 2537-2564.

Shiller, B.R. (2013), First degree price discrimination using big data. Brandeis Univ., Department of Economics.

Shin, H.S. (2009), "Securitisation and financial stability", The Economic Journal, No 119(536), pp. 309-332.

Smith, J.K. (1987), "Trade credit and informational asymmetry", The Journal of Finance, No 42(4), pp. 863-872.

Stein, J.C. (2002), “Information production and capital allocation: Decentralized versus hierarchical firms”, Journal of Finance, No 57(5), pp. 1891-1921.

Stein, J.C. (2010), "Securitization, shadow banking \& financial fragility”, Daedalus, No 139(4), pp. 41-51. 
Stiroh, K.J. and Rumble, A. (2006), "The dark side of diversification: The case of US financial holding companies", Journal of Banking \& Finance, No 30(8), pp. 21312161.

Stroebel, J. (2016), “Asymmetric information about collateral values", Journal of Finance, No 71(3), pp. 1071-1112.

Stulz, R. M. (2019), "Fintech, bigtech, and the future of banks", Journal of Applied Corporate Finance, No 31(4), pp. 86-97.

Thakor, A.V. (1999), "Fintech and banking: What do we know?", Journal of Financial Intermediation, forthcoming.

Van den Heuvel, S. (2002). "Does bank capital matter for monetary transmission?" FRBNY Economic Policy Review, 8(1).

Vives, X. (2010), Information and learning in markets: the impact of market microstructure, Princeton University Press.

Vives, X. (2019), "Digital disruption in banking”, The Annual Review of Financial Economics, No 11(1), pp. 243-272. 